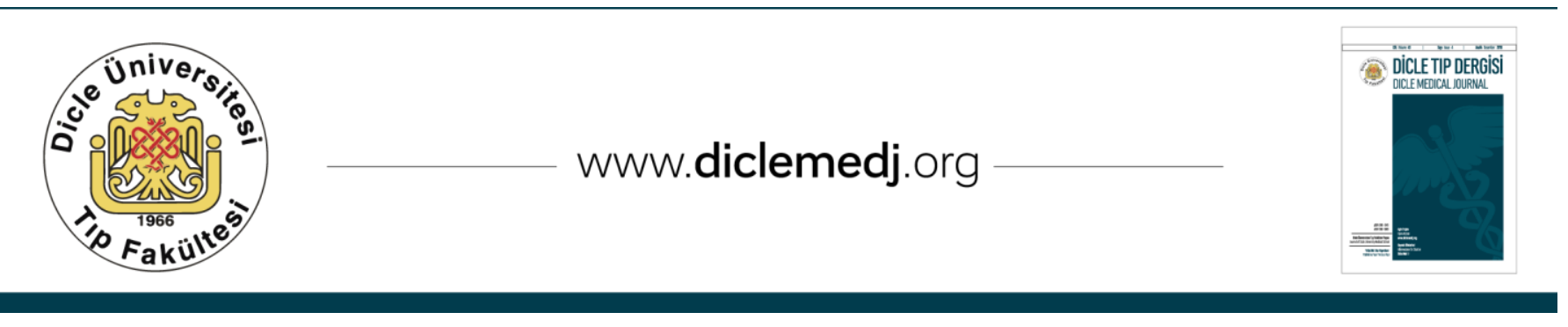

Case Report / Olgu Sunumu

\title{
Bone Hydatid Cyst Disease
}

\author{
Yavuz Pirhan"1, Necmi Kurt ${ }^{2}$ \\ 1 Amasya Sabuncuoglu Serafeddin Training and Research Hospital, Department of General Surgery, Faculty of Medicine, Amasya University, \\ Amasya, Turkey ORCID: 0000-0002-8234-6739 \\ 2 Amasya Sabuncuoglu Serafeddin Training and Research Hospital, Department of General Surgery, Faculty of Medicine, Amasya University, \\ Amasya, Turkey ORCID: 0000-0003-0659-317X
}

\begin{abstract}
Hydatid cyst disease in bone is a rare one (0.5-2.5\%) and 30\% is seen in the pelvis. This disease is difficult to diagnose as symptoms are similar to the bone malignancy. Forty five years old female patient was admitted to another hospital with the complaints of pain in lower-right quadrant of the abdomen radiating to the right leg. She had a palpable mass in this region and was sent to our hospital with a prediagnosis of bone malignancies. During the physical examination, a mass about $8 \times 10 \mathrm{~cm}$ semifixed to the right iliac bone was palpated. Serum tumor markers were within normal limits. Findings in magnetic resonance imaging was compatible with stage 3-4 hydatid cyst disease and also it was reported that cystadenocarsinoma should be considered in the differential diagnosis. Serological examination and fine needle aspiration biopsy were performed. Indirect hemagglutination test titer $1 / 2048(+)$ and biopsy results were consistent with hydatid cyst. Fifteen days prior to the surgery, the patient was given $10 \mathrm{mg} / \mathrm{kg}$ albendazole treatment. Mass containing daughter vesicles caused bone destruction in iliac bone were totally scraped.
\end{abstract}

Keywords: Hydatid cyst, bone hydatid cyst, differential diagnosis Kemik Kist Hidatik Hastalığı

DOI: $10.5798 /$ dicletip.362500

Yazıșma Adresi / Correspondence: Yavuz Pirhan, Amasya Sabuncuoglu Serafeddin Training and Research Hospital, Department of General Surgery, Faculty of Medicine, Amasya University, Amasya, Turkey e-mail: ypirhan@gmail.com 


\section{Kemik Kist Hidatik Hastalığı}

\section{Özet}

Kemikle iștirakli hidatik kist hastalığı nadirdir $(\% 0,5-2,5)$ ve \%30 oranında pelviste görülür. Davranış olarak kemik malignitesine benzediği için tanı konulması zordur. Bașka bir hastanede karın sağ alt kadranda ele gelen kitle ve bu bölgeden sağ bacağa yayılan ağrı yakınmasıyla tetkik edilen kırkbeș yaşında bayan hasta, kemik malignitesi ön tanısıyla hastanemize gönderildi. Fizik muayenede sağ iliak kemikle sınırları ayrılmayan yaklaşı $8 \times 10 \mathrm{~cm}$ semifikse kitle saptandı. Serum tümör belirteçleri normaldi. Manyetik rezonans görüntülemede kitlenin evre 3-4 kist hidatik ile uyumlu olabileceği ancak ayırıcı tanıda kistadenokarsinomanın da düşünülmesi gerektiği raporlandı. Serolojik inceleme ve iğne biyopsisi (İAB) yapıldı. İndirekt hemaglütinasyon testinde titre 1/2048(+) ve biyopsi sonucu hidatik kist ile uyumluydu. Hastaya ameliyat öncesi 15 gün albendazole $10 \mathrm{mg} / \mathrm{kg}$ verildi. Ameliyatta, iliak kemikte yıkım oluşturmuş içinde kız veziküllerin olduğu kitle kemikten sıyrılarak total olarak çıkarıldı.

Anahtar kelimeler: Kist hidatik, kemik kist hidatik, kemik kisti

\section{INTRODUCTION}

Hydatidosis, Echinococcus granulosus carnivores living in small intestines are caused by larval forms of parasitic disease. The disease is rarely detected in some parts of the body, such as spleen, kidney, brain, peritoneum, muscle and bone. That Hydatid cyst disease in sharing behavior resembles bone for bone malignancy is difficult to diagnose. For this reason, we wanted to share a rare case. The ethics committee was not approved because it was a case report and the patient was kept confidential.

\section{CASE REPORT}

Fourty-five years old female patient was admitted to another hospital with the complaints of dull pain in the lower right abdomen lasting 10 days, a palpable swelling in the same area about 2 years and radiating pain in the right leg pain. She was referred to our clinic with the diagnosis of malignancy. Abdominal ultrasonography and computed tomography in the different center within 6 months periods, showed no change in the dimensions of $10 \times 6.5 \mathrm{~cm}$ mass with septa and cystic / necrotic components and also destruction in the right iliac bone. During physical examination, painful $8-10 \mathrm{~cm}$ semifixed mass in the right iliac wing was palpated. Routine blood examination, carcinoembryonic antigen, cancer antigen (CA) 19-9, CA 125 were normal. The patient was consulted by radiology department and pelvic magnetic resonance imaging (MRI) examination was performed. The result was compatible with hydatid cyst stage 3-4 lesions, and a very low probability of the appearance of cysts in the form of adenocarcinoma was reported. Image of the MRI was given [Figure 1-2]. Serological examination and fine needle aspiration biopsy (FNAB) was performed, Indirect Hemaglutination (IHA) hydatid cyst $1 / 2048$ $(+)$, hydatid cyst was diagnosed as a result of needle biopsy. The patient had the treatment of albendazole $10 \mathrm{mg} / \mathrm{kg}$ preoperatively. Total excision of the lesion containing daughter vesicles was performed. She had no postoperative complications, and pathology report was also consistent with hydatid cyst disease. Albendazole treatment was completed to 3 months. She was monitored for 48 months without any problems. 


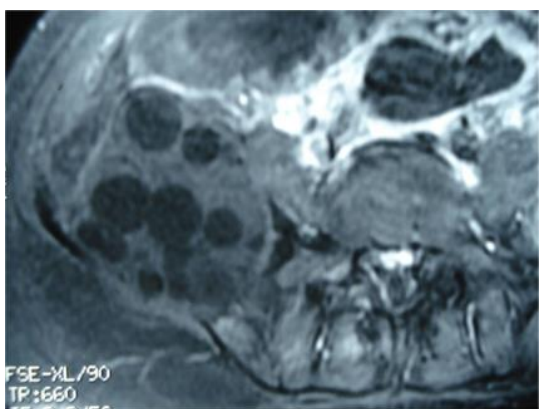

Figure 1: Appearance of multiple cysts in MRI (Transverse section)

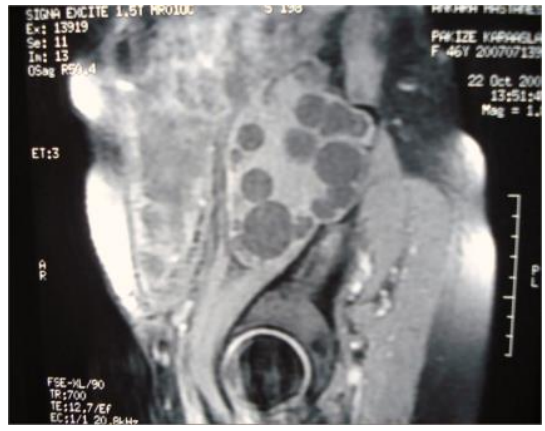

Figure 2: Appearance of multiple cysts in MRI (Sagittal section)

\section{DISCUSSION}

Echinococcosis granulosus hydatid disease is caused by the liver (66\%), lung (22\%) and other visceral organs $(10 \%)$ and rarely seen together $(0.5-2.5 \%)$ and can be seen in the skeletal system ${ }^{1-3}$. Skeletal system involvement is the most frequently, reported in the pelvis by $30 \%$. As it shows similarity with the behavior of bone tumors, differential diagnosis of this disease should be well performed and treatment should be initiated after diagnosis 4 . Cyst serology and tumor markers for differential diagnosis should be done first. Imaging, X-ray calcified cyst walls can be seen directly, but in our case direct graphy remained inadequate. Ultrasonography and computed tomography is helpful for the diagnosis. However, the most sensitive method is the MRI examination. Bone malignancies and hydatic cyst disease are treated surgically however, more aggressive surgery is needed in malignant diseases. In addition, patients with hydatid disease should be treated with antiparasitic drugs before surgery. In the past years these cases were considered as malignant diseases and hemipelvectomy surgery was applied ${ }^{5-8}$. Current surgical treatment is wide excision of hydatid cyst cavity after the application of hypertonic solution. And also albendazol treatment for at least 1 month or mebendazol for at least 3 months are suggested after surgery. Recently, systemic chemotherapy is recommended as a benzimadozole, particulate mebandozol, albendazole, and combination treatment in clinical and experimental studies ${ }^{9-}$ 10.

Bone hydatid cyst disease is a benign disease and may be confused with malignant diseases of the bone because of the behavior. Therefore, the differential diagnosis should be kept in mind. Treatment is extended surgical excision and albendazol.

Declaration of Conflicting Interests: The authors declare that they have no conflict of interest.

Financial Disclosure: No financial support wasreceived.

\section{REFERENCES}

1. Alessandro M, Pier GP. Hydatidosis of the pelvis: A case report with a 25- year fellow-up. Arch Orthop Trauma Surge 2004; 124: 203-5.

2. Cosso S, Calderon JE. Su diun caso di echinococcosi primitiva dell'ileo. Chirb Organi Mov 1985;70:195-7.

3. De Cristofaro R, Ruggieri P, Biagini R, Picci P. Case report 629: Osseous hydatidosis. Skeletal Radiol 1990; 19: 461-4.

4. Loudiye H, Aktaou S, Hassikou H. Hydatid dissease of bone. Review of 11 cases. Joint Bone Spine 2003; 70: 353-5.

5. Ocete G, Guerrero A, Diaz-Peletier R. Experience in the treatment of osseous hydatidosis. Int Ortho 1986; 10: 141-5.

6. Gorun N. La desarticolation de hanche de necessite dans. Echinococcose etendue du femur. Rev Chir Orthop Reparatrice Appar Mot 1992;78:255-7. 
7. Helenon 0, Folinais D, David M, Blangy S, Sibert A. Hydatidose osseuse de la ceinture pelvienne. J Radiol 1986; 67: 515-21.

8. Wirbel RJ, Scholde M. Mega prosthetic replacement of the pelvis. Acta Orthop Scand 1999; 70: 348-52.
9. Song $\mathrm{XH}$, Ding LW, Wen H. Bone hydatiddissease. Postgrad Med J. Aug 2007; 83(982):536-42.

10.İrfan Eser, Ahmet Şeker, Şamil Günay, Mehmet Salih Aydın, Zafer Hasan Ali Sak. The efficacy of albendazole treatment in a patient with hydatid cyst disease of multiorgan involvement. Dicle Medical Journal, 2013; 40: 688-90. 